\title{
Effectiveness of Serbian Health Care System in 2014
}

\author{
Ivan Stevanović ${ }^{1}$, Milena Gajić-Stevanović \\ "Health Monitor" Association, Belgrade, Serbia; \\ 2Public Health Institute of Serbia "Dr Milan Jovanović Batut", Belgrade, Serbia
}

\begin{abstract}
SUMMARY
The European Health Consumer Index (EHCl) is a project that since 2006 has been comparing and ranking health care systems of European countries, from the perspective of patients (consumers) - users of the health care system. Its purpose was to set standards for well functioning and organized health care. The aim of this study was to assess the state of Serbian health care system from the perspective of the European health consumer index and propose recommendations for its improvement and functioning in accordance with European standards. The assessment of the health care system is based on pre-determined forty-eight indicators divided into six groups. According to these indicators, scoring and ranking of countries was done (maximum score for a particular indicator was 3 , and the minimum was 1 ). As per European Health Consumer Index the Republic of Serbia is ranked at 33rd place, with total of 473 points, while Netherlands has been found on the top of the list for years (this year 898 points).

Keywords: health system; European Health Consumer Index; indicators of the health system
\end{abstract}

\section{INTRODUCTION}

Due to medical advances people are expected to live longer and in the case of diseases to receive the most effective medications as well as necessary diagnostic and medical procedures, both in detection and treatment of disease. Throughout the Europe the incidence of chronic diseases is on the rise and, consequently financial burden related to health care. There is a growing concern of politicians and health experts that existing health systems might not be able to respond to the growing demands of health care. Most countries are now reforming their health care systems in the direction of putting the patient in the focus of health care, trying to preserve and improve functioning of their health systems with less allocation of public funds.

The European Health Consumer Index (EHCI) is a project that had started in 2006 and since then its goal is to compare and rank health systems of European countries, from the perspective of patients (consumers) - users of the health care system with basic aim to set standards for well-functioning and organized health care. In 2014 there were 36 countries included in EHCI estimation, among them was the Republic of Serbia.

The aim of this study was to assess the state of Serbian health care system from the perspective of EHCI compared to neighbouring countries and countries of the European Union and propose recommendations for its improvement and functioning in accordance to European standards.

\section{INDICATORS OF THE HEALTH CARE SYSTEM EFFICIENCY}

The assessment of health care system was made on the basis of pre-determined forty-eight indicators, divided into six groups:
- The first group included indicators that describe the rights of patients and their awareness;

- The second group of indicators assessed the availability of health care (waiting times for the treatment);

- The third group of indicators evaluated the outcomes of the treatment;

- The fourth group observed the range and scope of services provided in health care;

- The fifth group assessed prevention;

- The sixth group assessed pharmaceuticals use.

Based on the indicators scoring and ranking of countries was done, where the highest score for a given indicator was 3 and the lowest 1 . The resulting points were multiplied by a coefficient determined for each group of indicators, so that the total sum amounted 1000. The score in each individual group is shown in the Table 1.

Table 1. Relative weight of the six observed groups presented in scores

Tabela 1. Relativni značaj šest posmatranih grupa predstavljenih bodovima

\begin{tabular}{|c|l|c|}
\hline \multicolumn{2}{|l|}{$\begin{array}{l}\text { Group } \\
\text { Grupa }\end{array}$} & $\begin{array}{c}\text { Maximum scores } \\
\text { Maksimalni broj } \\
\text { bodova }\end{array}$ \\
\hline I & $\begin{array}{l}\text { Patient rights and information } \\
\text { Prava pacijenata i njihova informisanost }\end{array}$ & 150 \\
\hline II & $\begin{array}{l}\text { Accessibility of health care } \\
\text { Pristupačnost zdravstvene zaštite }\end{array}$ & 225 \\
\hline III & $\begin{array}{l}\text { Outcomes of the treatment } \\
\text { Ishodi lečenja }\end{array}$ & 250 \\
\hline IV & $\begin{array}{l}\text { Range and reach of services } \\
\text { Spektar i dostupnost usluga }\end{array}$ & 150 \\
\hline V & $\begin{array}{l}\text { Prevention } \\
\text { Prevencija }\end{array}$ & 125 \\
\hline VI & $\begin{array}{l}\text { Pharmaceuticals } \\
\text { Lekovi }\end{array}$ & 100 \\
\hline $\begin{array}{l}\text { Total } \\
\text { Ukupno }\end{array}$ & 1000 \\
\hline
\end{tabular}


The current study compared the health care system of the Republic of Serbia with health care systems of the neighbouring countries (Croatia, Montenegro, Macedonia, Bulgaria, Albania and Slovenia) and highly developed countries of European Union with the highest scores (Italy, Spain, Netherlands).

\section{Group I - Patients' rights and their awareness were evaluated by the following indicators:}

1. Healthcare law based on Patients' Rights

2. Patient organisations involved in decision making

3. No-fault malpractice insurance

4. Right to second opinion

5. Access to own medical record

6. Registry of bona fide doctors

7. Web or $24 / 7$ telephones HC info with interactivity

8. Cross-border care financed from home

9. Provider catalogue with quality ranking

10. EPR penetration

11. Patients' access to on-line booking of appointments?

12. e-prescriptions

In connection to the rights of patients and their awareness, the highest score was achieved by Netherlands (35) and Macedonia (33) which with this indicator stood out not only from the other countries in the region, but also from Italy (25) and Spain (23). In this segment only Bul- garia (19) had lower score than Serbia (20). Table 2 shows that out of former Yugoslav Republics, only Macedonia achieved excellent results in most indicators about rights and patients' awareness.

Serbia showed low score (20 points) but it is on the right track. However, there is room for improvement in:

- patients' involvement in health policy through raising their awareness

- establishing a registry of conscientious physicians and catalog-ranked health providers

- accessing to electronic patient record at the entire territory, provide phone scheduled appointments to physicians and availability of electronic prescriptions.

\section{Group II - Accessibility to health care (waiting for treatment) was assessed by the following indicators:}

1. Family doctor same day access

2. Direct access to Specialist

3. Major elective surgery $<90$ days

4. Cancer therapy $<21$ days

5. CT scan $<7$ days

6. A\&E waiting Times

As it can be seen from Table 3, Macedonia was the best in assessing the availability of health services in 2014 with 17 points, Spain with eight points was the weakest. Serbia scored only one point more than Spain, and eight points less

Table 2. Patient rights and their awareness in 2014

Tabela 2. Prava pacijenata i njihova informisanost u 2014. godini

\begin{tabular}{|c|c|c|c|c|c|c|c|c|c|c|}
\hline $\begin{array}{l}\text { Indicator } \\
\text { Pokazatelj }\end{array}$ & 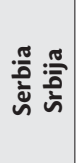 & 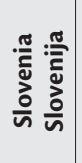 & 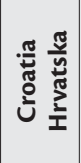 & 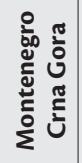 & 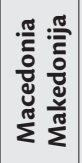 & 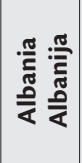 & 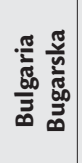 & 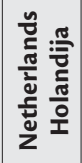 & 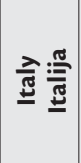 & 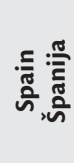 \\
\hline $\begin{array}{l}\text { Healthcare law based on patients' rights } \\
\text { Zdravstveni zakon zasnovan na pravima pacijenata }\end{array}$ & 3 & 3 & 3 & 2 & 3 & 3 & 1 & 3 & 3 & 3 \\
\hline $\begin{array}{l}\text { Patient organisations involved in decision making } \\
\text { Organizacije pacijenata }\end{array}$ & 2 & 2 & 2 & 1 & 3 & 3 & 3 & 3 & 2 & 1 \\
\hline $\begin{array}{l}\text { No-fault malpractice insurance } \\
\text { Osiguranje od greške u lečenju }\end{array}$ & 2 & 2 & 1 & 2 & 2 & 1 & 1 & 3 & 2 & 1 \\
\hline $\begin{array}{l}\text { Right to second opinion } \\
\text { Pravo na drugo mišljenje }\end{array}$ & 2 & 2 & 3 & 3 & 3 & 2 & 1 & 3 & 2 & 2 \\
\hline $\begin{array}{l}\text { Access to own medical record } \\
\text { Pristup svom zdravstvenom kartonu }\end{array}$ & 2 & 2 & 2 & 3 & 3 & 3 & 2 & 3 & 2 & 2 \\
\hline $\begin{array}{l}\text { Registry of bona fide doctors } \\
\text { Registar savesnih lekara }\end{array}$ & 1 & 2 & 2 & 1 & 3 & 3 & 3 & 3 & 3 & 1 \\
\hline $\begin{array}{l}\text { Web or } 24 / 7 \text { telephone health care info with interactivity } \\
\text { 24-časovni telefon za zdravstvenu pomoć }\end{array}$ & 2 & 2 & 1 & 2 & 3 & 1 & 1 & 3 & 3 & 3 \\
\hline $\begin{array}{l}\text { Cross-border care seeking financed from home } \\
\text { Međugranična nega finansirana od strane zemlje u kojoj je osoba državljanin }\end{array}$ & 2 & 1 & 1 & 2 & 2 & 2 & 1 & 3 & 1 & 1 \\
\hline $\begin{array}{l}\text { Provider catalogue with quality ranking } \\
\text { Katalog pružalaca usluga s ocenama }\end{array}$ & 1 & 1 & 1 & 1 & 2 & 1 & 1 & 3 & 2 & 1 \\
\hline $\begin{array}{l}\text { Electronic personal record penetration } \\
\text { Dostupnost elektronskog kartona pacijentu }\end{array}$ & 1 & 2 & 3 & 2 & 3 & 1 & 3 & 3 & 2 & 2 \\
\hline $\begin{array}{l}\text { Patients' access to on-line booking of appointments? } \\
\text { Mogućnost online zakazivanja posete lekaru }\end{array}$ & 1 & 3 & 3 & 1 & 3 & 1 & 1 & 2 & 2 & 3 \\
\hline $\begin{array}{l}\text { E-prescriptions } \\
\text { Elektronski recepti }\end{array}$ & 1 & 1 & 3 & 1 & 3 & 1 & 1 & 3 & 1 & 3 \\
\hline $\begin{array}{l}\text { Total } \\
\text { Ukupno }\end{array}$ & 20 & 23 & 25 & 21 & 33 & 22 & 19 & 35 & 25 & 23 \\
\hline
\end{tabular}

1 - weak; 2 - good or incomparable; 3 - excellent

1 - slabo; 2 - dobro ili neuporedivo; 3 - odlično 
Table 3. Accessibility (waiting times for treatment) in 2014

Tabela 3. Dostupnosti zdravstvene službe (čekanje na lečenje) u 2014. godini

\begin{tabular}{|c|c|c|c|c|c|c|c|c|c|c|}
\hline $\begin{array}{l}\text { Indicator } \\
\text { Pokazatelj }\end{array}$ & 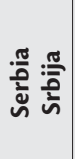 & 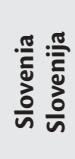 & 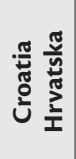 & 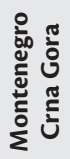 & 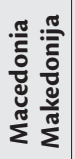 & 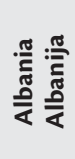 & 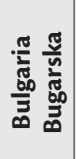 & 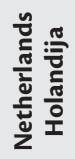 & 舫 & 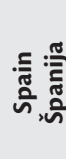 \\
\hline $\begin{array}{l}\text { Family doctor same day access } \\
\text { Poseta lekaru opšte medicine istog dana }\end{array}$ & 3 & 3 & 3 & 2 & 3 & 3 & 3 & 3 & 3 & 1 \\
\hline $\begin{array}{l}\text { Direct access to specialist } \\
\text { Direktan dolazak do specijaliste }\end{array}$ & 1 & 3 & 2 & 1 & 2 & 3 & 2 & 1 & 2 & 1 \\
\hline $\begin{array}{l}\text { Major elective surgery }<90 \text { days } \\
\text { Čekanje na velike izabrane operacije manje od } 90 \text { dana }\end{array}$ & 1 & 1 & 1 & 1 & 3 & 3 & 3 & 3 & 2 & 1 \\
\hline $\begin{array}{l}\text { Cancer therapy }<21 \text { days } \\
\text { Čekanje na terapiju za kancer manje od } 21 \text { dan }\end{array}$ & 1 & 3 & 3 & 2 & 3 & 2 & 2 & 2 & 2 & 2 \\
\hline $\begin{array}{l}\text { CT scan }<7 \text { days } \\
\text { Čekanje na CT skener manje od } 7 \text { dana }\end{array}$ & 1 & 2 & 1 & 1 & 3 & 2 & 1 & 3 & 1 & 1 \\
\hline $\begin{array}{l}\text { A\&E waiting times } \\
\text { Čekanje na prijem u hitnu službu }\end{array}$ & 2 & 2 & 3 & 3 & 3 & 3 & 2 & 3 & 1 & 2 \\
\hline $\begin{array}{l}\text { Total } \\
\text { Ukupno }\end{array}$ & 9 & 14 & 13 & 10 & 17 & 16 & 13 & 15 & 11 & 8 \\
\hline
\end{tabular}

1 - weak; 2 - good or incomparable; 3 - excellent

1 - slabo; 2- dobro ili neuporedivo; 3 - odlično

than Macedonia, with availability of health services considerably weaker than Albania (16), Netherlands (15), Slovenia (14), Croatia (13) and Bulgaria (13). Access to health care is very important indicator in assessing the ability of health care system to meet the needs of population.

In order for Serbian health services to become more accessible, it is necessary to determine objective and subjective reasons for difficult access to specialists as well as necessary diagnostic, operational procedures and therapy. Macedonia could serve as an example to Serbia how to improve availability of health services (with possibility of same day access to family doctor) (score 3).

\section{Group III - The third set of indicators evaluated treat- ment outcomes through the following indicators:}

1. Decrease of CVD (cardiovascular diseases) deaths

2. Decrease of stroke deaths

3. Infant deaths

4. Cancer survival

5. Preventable Years of Life Lost

6. MRSA (Methicillin-resistant Staphylococcus aureus) infections

7. Abortion rates

8. Depression

Treatment outcomes, as the most important indicators for well functioning health care system, clearly distinguished economically stronger countries such as Netherlands (23), Spain (19), Italy (16) and Slovenia (15), from our neighbouring countries. Netherlands leads with twenty-three points in this category, with nearly three times more points than Serbia as the last one (8). Outcomes of treatment were also somewhat better in Croatia (15) Montenegro (15), followed by Bulgaria (12), Albania (10) and Macedonia (10) (Table 4).

Devastating output effects of the Serbian health care system, with no single parameter that achieved good or excellent score, suggests need for serious reform of the health care system. Ten years of reforming health care system, with large financial investments through various projects and donations has not produced progress in any of indicators.

In the following period these questions should be answered:

- Why is Serbia so much behind other European countries and countries in the region?

- Why such large investments in reforming the health care system have not produced the expected effects?

- Is economic inferiority of the country the main reason for poor output effects in the functioning of health care system?

Group IV - The fourth group assessed the range and scope of services provided by the following indicators:

1. Equity of health care systems

2. Cataract operations per 100000 people age $65+$

3. Kidney transplants per million of population

4. Is dental care included in the public healthcare offering?

5. Informal payments to doctors

6. Long term care for elderly

7. $\%$ of dialysis done outside of clinic

8. Caesarean Sections

In the fourth group which evaluated the range and scope of services provided in the health care system, the highest score was awarded to Netherlands (24), followed by Spain (18), Slovenia (18), Croatia (16), Macedonia (15) and Italy (14) with the least points achieved by Albania and Bulgaria (9). The range and scope of services provided in Serbia were assessed with 11 points, slightly more than Albania and Bulgaria (Table 5). Indicator five (informal payments to doctors) showed clearly corruption problem in countries of the region, and a small number of kidney 
transplantations. The number of kidney transplantations demonstrates again the best results in the Netherlands and Spain, and from countries in the region good results are only in Croatia.

Compliment to Serbian health care system is slightly higher percentage of dialysis undertaken out of the clinics in comparison to all other countries in the region. This shows the consistency of the policy shift towards satisfying the needs of population with cheaper and more effective methods of treatment.

\section{Group V - The parameters related to the output effects of prevention:}

1. Infant immunization

2. Blood pressure

3. Smoking Prevention

4. Alcohol Prevention

5. Physical Activity

6. HPV Vaccination

7. Traffic deaths

Table 4. Treatment outcomes in 2014

Tabela 4. Ishodi lečenja u 2014. godini

\begin{tabular}{|c|c|c|c|c|c|c|c|c|c|c|}
\hline $\begin{array}{l}\text { Indicator } \\
\text { Pokazatelj }\end{array}$ & 旁: & 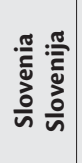 & 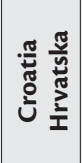 & 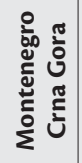 & 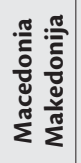 & 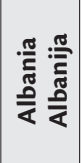 & 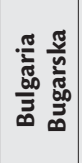 & 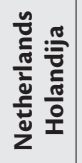 & 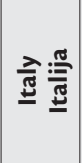 & 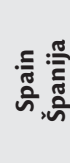 \\
\hline $\begin{array}{l}\text { Decrease of cardiovascular diseases deaths } \\
\text { Smanjenje smrtnosti od kardiovaskularnih bolesti }\end{array}$ & 1 & 3 & 1 & 1 & 1 & 1 & 3 & 3 & 2 & 2 \\
\hline \begin{tabular}{|l|} 
Decrease of stroke deaths \\
Smanjenje smrtnosti od moždanog udara
\end{tabular} & 1 & 2 & 2 & 3 & 1 & 1 & 1 & 3 & 2 & 3 \\
\hline $\begin{array}{l}\text { Infant deaths } \\
\text { Smrtnost odojčadi }\end{array}$ & 1 & 3 & 3 & 2 & 1 & 1 & 1 & 3 & 3 & 3 \\
\hline $\begin{array}{l}\text { Cancer survival } \\
\text { Preživljavanje kod obolelih od kancera }\end{array}$ & 1 & 2 & 1 & 1 & 1 & 1 & 1 & 2 & 2 & 2 \\
\hline $\begin{array}{l}\text { Preventable years of life lost } \\
\text { Izgubljene godine života koje mogu da se preveniraju }\end{array}$ & 1 & 2 & 2 & 1 & 2 & 2 & 1 & 3 & 3 & 3 \\
\hline \begin{tabular}{|l|} 
MRSA infections \\
Procenat bolničkih infekcija usled MRSA
\end{tabular} & 1 & 2 & 1 & 2 & 1 & 1 & 2 & 3 & 1 & 1 \\
\hline $\begin{array}{l}\text { Abortion rates } \\
\text { Procenat abortusa }\end{array}$ & 1 & 3 & 3 & 3 & 2 & 2 & 1 & 3 & 2 & 2 \\
\hline $\begin{array}{l}\text { Depression } \\
\text { Procenat depresije }\end{array}$ & 1 & 2 & 2 & 2 & 1 & 1 & 2 & 3 & 1 & 2 \\
\hline \begin{tabular}{|l|} 
Total \\
Ukupno
\end{tabular} & 8 & 19 & 15 & 15 & 10 & 10 & 12 & 23 & 16 & 18 \\
\hline
\end{tabular}

1 - weak; 2 - good or incomparable; 3 - excellent

MRSA - Methicillin-resistant Staphylococcus aureus

1 - slabo; 2- dobro ili neuporedivo; 3 - odlično

MRSA - Staphylococcus aureus koji je rezistentan na meticilin

Table 5. Range and reach of services provided in 2014

Tabela 5. Raspon i domet pruženih usluga u 2014. godini

\begin{tabular}{|c|c|c|c|c|c|c|c|c|c|c|}
\hline $\begin{array}{l}\text { Indicator } \\
\text { Pokazatelj }\end{array}$ & 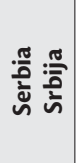 & 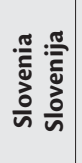 & 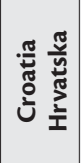 & 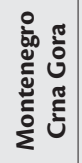 & 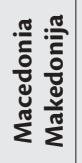 & 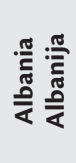 & 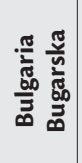 & 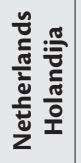 & 긑 & 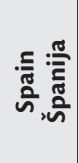 \\
\hline $\begin{array}{l}\text { Equity of healthcare systems } \\
\text { Pravičnost zdravstvenog sistema }\end{array}$ & 1 & 2 & 3 & 1 & 3 & 1 & 1 & 3 & 2 & 2 \\
\hline $\begin{array}{l}\text { Cataract operations per } 100,000 \text { age } 65+ \\
\text { Broj operacija katarakte na } 100.000 \text { stanovnika starijih od } 65 \text { godina }\end{array}$ & 1 & 3 & 2 & 2 & 2 & 2 & 1 & 3 & 2 & 2 \\
\hline $\begin{array}{l}\text { Kidney transplants per million people } \\
\text { Broj transplantacija bubrega na } 1.000 .000 \text { ljudi }\end{array}$ & 1 & 1 & 3 & 1 & 1 & 1 & 1 & 3 & 1 & 3 \\
\hline $\begin{array}{l}\text { Is dental care included in the public healthcare? } \\
\text { Uključenost stomatološke zaštite u javnu zdravstvenu zaštitu }\end{array}$ & 2 & 3 & 3 & 2 & 3 & 1 & 2 & 3 & 2 & 2 \\
\hline $\begin{array}{l}\text { Informal payments to doctors } \\
\text { Neformalna plaćanja doktorima }\end{array}$ & 1 & 3 & 1 & 1 & 2 & 1 & 1 & 3 & 3 & 3 \\
\hline $\begin{array}{l}\text { Long term care for the elderly } \\
\text { Dugotrajna nega za stariju populaciju }\end{array}$ & 1 & 2 & 1 & 2 & 1 & 1 & 1 & 3 & 1 & 2 \\
\hline $\begin{array}{l}\text { Percent of dialyses done outside of clinic } \\
\text { Procenat dijaliza urađenih van klinike }\end{array}$ & 2 & 1 & 1 & 1 & 1 & 1 & 1 & 3 & 2 & 2 \\
\hline $\begin{array}{l}\text { Caesarean sections per } 1,000 \text { newborns } \\
\text { Carski rez u odnosu na } 1.000 \text { živorođenih }\end{array}$ & 2 & 3 & 2 & 2 & 2 & 1 & 1 & 3 & 1 & 2 \\
\hline $\begin{array}{l}\text { Total } \\
\text { Ukupno }\end{array}$ & 11 & 18 & 16 & 12 & 15 & 9 & 9 & 24 & 14 & 18 \\
\hline
\end{tabular}

1 - weak; 2 - good or incomparable; 3 - excellent

1 - slabo; 2 - dobro ili neuporedivo; 3 - odlično 
The highest score in this group of parameters achieved Spain (18), followed by Macedonia and Italy with 16 points and Slovenia with 15 points. The lowest score was achieved in Croatia (10). Serbia is somewhere in the middle with 13 points (Table 6). Surprisingly, Macedonia achieved higher score on prevention than Netherlands. Smoking prevention did not yield expected results in any country in the region, not even in the Netherlands. This calls for certain corrections, in order to achieve better efficiency.
In Serbia, there is room for improving output effects of preventive activities by increasing the percentage of vaccinated infants, greater engagement in the prevention of smoking and alcohol consumption, especially in the "National Program for Teens" implementation. Compared to the neighbouring countries Serbia's highlights are good results of the activities undertaken on physical activity and reduction of high blood pressure among population.

Table 6. Prevention achieved in 2014

Tabela 6. Preventivne aktivnosti u 2014. godini

\begin{tabular}{|c|c|c|c|c|c|c|c|c|c|c|}
\hline $\begin{array}{l}\text { Indicator } \\
\text { Pokazatelj }\end{array}$ & 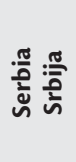 & 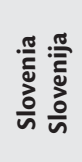 & 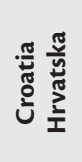 & 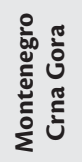 & 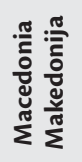 & 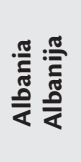 & 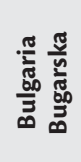 & 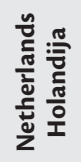 & 忞芯 & 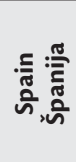 \\
\hline $\begin{array}{l}\text { Infant immunization } \\
\text { Vakcinacija odojčadi }\end{array}$ & 2 & 3 & 3 & 2 & 3 & 3 & 2 & 2 & 2 & 3 \\
\hline $\begin{array}{l}\text { Blood pressure } \\
\text { Visina krvnog pritiska }\end{array}$ & 2 & 1 & 1 & 1 & 1 & 1 & 1 & 3 & 3 & 3 \\
\hline $\begin{array}{l}\text { Smoking prevention } \\
\text { Prevencija pušenja }\end{array}$ & 1 & 1 & 1 & 1 & 1 & 1 & 1 & 1 & 1 & 2 \\
\hline $\begin{array}{l}\text { Alcohol prevention } \\
\text { Prevencija alkohola }\end{array}$ & 2 & 2 & 2 & 3 & 3 & 3 & 2 & 2 & 3 & 2 \\
\hline $\begin{array}{l}\text { Physical activity } \\
\text { Fizička aktivnost }\end{array}$ & 3 & 3 & 1 & 2 & 3 & 2 & 1 & 1 & 2 & 2 \\
\hline $\begin{array}{l}\text { HPV vaccination } \\
\text { HPV vakcinacija }\end{array}$ & 1 & 3 & 1 & 2 & 3 & 1 & 3 & 3 & 3 & 3 \\
\hline $\begin{array}{l}\text { Traffic deaths } \\
\text { Smrtnost u saobraćaju }\end{array}$ & 2 & 2 & 1 & 2 & 2 & 1 & 2 & 3 & 2 & 3 \\
\hline $\begin{array}{l}\text { Total } \\
\text { Ukupno }\end{array}$ & 13 & 15 & 10 & 13 & 16 & 12 & 12 & 15 & 16 & 18 \\
\hline
\end{tabular}

1 - weak; 2 - good or incomparable; 3 - excellent

$\mathrm{HPV}$ - human papilloma virus

1 - slabo; 2- dobro ili neuporedivo; 3 - odlično

$\mathrm{HPV}$ - humani papiloma virus

Table 7. Pharmaceuticals use in 2014

Tabela 7. Korišćenje farmaceutskih proizvoda u 2014. godini

\begin{tabular}{|c|c|c|c|c|c|c|c|c|c|c|}
\hline $\begin{array}{l}\text { Indicator } \\
\text { Pokazatelj }\end{array}$ & 施 & 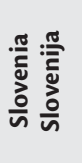 & 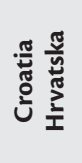 & 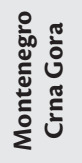 & 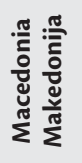 & 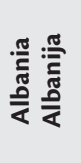 & 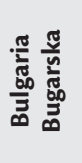 & 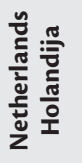 & 즡 & 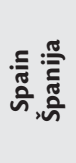 \\
\hline $\begin{array}{l}\text { Rx pharmaceutical subsidy } \\
\text { Ukupna prodaja farmaceutskih proizvoda koji su } \\
\text { plaćeni javnim subvencijama }\end{array}$ & 1 & 2 & 2 & 1 & 3 & 1 & 1 & 3 & 1 & 3 \\
\hline $\begin{array}{l}\text { Layman-adapted pharmacopoeia } \\
\text { Postojanje Lajman-adaptirane farmakopeje dostupne } \\
\text { javnosti }\end{array}$ & 3 & 3 & 3 & 2 & 3 & 1 & 3 & 3 & 3 & 2 \\
\hline $\begin{array}{l}\text { Novel cancer drugs deployment rate } \\
\text { Stopa primene novih lekova za rak }\end{array}$ & 1 & 2 & 1 & 2 & 2 & 2 & 1 & 2 & 2 & 2 \\
\hline $\begin{array}{l}\text { Access to new drugs (time to subsidy) } \\
\text { Dostupnost novih lekova }\end{array}$ & 2 & 1 & 2 & 2 & 2 & 1 & 2 & 2 & 1 & 1 \\
\hline $\begin{array}{l}\text { Arthritis drugs } \\
\text { Korišćenje lekova za artritis }\end{array}$ & 1 & 2 & 1 & 2 & 2 & 2 & 1 & 2 & 2 & 2 \\
\hline $\begin{array}{l}\text { Metformin use } \\
\text { Korišćenje metmorfina }\end{array}$ & 2 & 1 & 2 & 1 & 1 & 2 & 2 & 3 & 2 & 2 \\
\hline $\begin{array}{l}\text { Antibiotics per capita } \\
\text { Korišćenje antibiotika po glavi stanovnika }\end{array}$ & 2 & 3 & 2 & 1 & 2 & 2 & 2 & 3 & 1 & 2 \\
\hline $\begin{array}{l}\text { Total } \\
\text { Ukupno }\end{array}$ & 12 & 14 & 13 & 11 & 15 & 11 & 12 & 18 & 12 & 14 \\
\hline
\end{tabular}

1 - weak; 2 - good or incomparable; 3 - excellent

1 - slabo; 2 - dobro ili neuporedivo; 3 - odlično 
Group VI - The sixth group assessed the use of pharmaceuticals through the following indicators:

1. Rx pharmaceutical subsidy

2. Layman-adapted pharmacopoeia?

3. Novel cancer drugs deployment rate

4. Access to new drugs (time to subsidy)

5. Arthritis drugs use

6. Metformin use

7. Antibiotics per capita

In this group of parameters, Netherlands was again at the first place, with total of 18 points achieved followed by Macedonia (15), Spain (14), Slovenia (14) and Croatia (13). The lowest score was achieved by Montenegro and Albania (11) while Italy, Bulgaria and Serbia reached a little bit higher score (12) (Table 7).

In the assessment of indicators and use of pharmaceutical products paid by public subsidies, Serbia received poor marks. The rate of application of specific new concepts and new drugs for the treatment of cancer in Serbia must improve, as well as the use of drugs for arthritis treatment, in order to get closer to European Union countries' standards.

\section{CONCLUSION AND RECOMMENDATIONS}

Health care system in Serbia, according to the European Health Consumer index (EHCI), was placed on 33rd place with 473 points out of a maximum 1000. At the top of the list for years is Netherlands with the total of 898 points achieved this year. This ranking and applied parameters, provide clear insight into what is good in health care system of Serbia and what needs to be improved in order to reach the ultimate goal - satisfied and healthy userconsumer of health care system.
Positive developments in Serbia have been made in improving the access to primary health care, information about medicines, increased percentage of dialysis performed outside the clinics, as well as good results of activities undertaken to reduce the high rates of high blood pressure among population.

In order for users of health care in the Republic of Serbia to be healthy and happy with health care system the following parameters should be improved:

- involvement of patients in health policy and increased patients' awareness,

- activities on prevention and promotion,

- activities to reduce adverse treatment outcomes,

- activities to increase access to health care,

- activities to reduce infant mortality,

- activities to reduce the percentage of patients with cancer,

- activities aimed to prevent corruption in health care Evaluation of Serbian health care system effectiveness from the perspective of EHCI allows us to define recommendations in order to comply with European standards, and ultimately, achieve satisfaction of users/consumers.

\section{REFERENCES}

1. Björnberg A, Hjertqvist J. Euro Health Consumer Index 2014 Report. Health Consumer Powerhouse, 27.01.2015.

2. WHO. European Health for All database (HFA-DB). Copenhagen: WHO Regional Office for Europe; 2014.

3. WHO. Health Accounts. Available from: http://www.who.int/nha/ en/.

4. Eurostat. Available from: http://ec.europa.eu/eurostat

5. Heijink R, Renaud T. Cost-of-illness studies: a five-country methodological comparison (Australia, Canada, France, Germany and the Netherlands). Questions d'économie de la Santé. 2009; 143:1-6. 


\title{
Efikasnost zdravstvenog sistema Republike Srbije u 2014. godini
}

\author{
Ivan Stevanović ${ }^{1}$ Milena Gajić-Stevanović2 \\ 'Udruženje „Zdravstveni monitor", Beograd, Srbija; \\ ${ }^{2}$ Institut za javno zdravlje Srbije „Dr Milan Jovanović Batut“, Beograd, Srbija
}

\begin{abstract}
KRATAK SADRŽAJ
Evropski zdravstveni potrošački indeks $(\mathrm{EHCl})$ je projekat kojim se od 2006. godine porede i rangiraju zdravstveni sistemi evropskih zemalja iz ugla pacijenata (potrošača) - korisnika zdravstvenog sistema, s osnovnim ciljem postavljanja standarda za dobro funkcionisanje i organizaciju zdravstva. Cilj ovog rada je bio da se proceni stanje srpskog zdravstva iz ugla EHCl i predlože preporuke za njegovo unapređenje i funkcionisanje u skladu s normama evropskih standarda. Procena zdravstvenih sistema je urađena na osnovu unapred određenih 48 pokazatelja, raspoređenih u šest grupa. Na osnovu ovih pokazatelja je urađeno bodovanje i rangiranje zemalja (najveća ocena za određeni pokazatelj bila je 3, a najmanja 1). Republika Srbija je, prema EHCl, zauzela 33. mesto sa 473 boda, dok je na vrhu liste već godinama Holandija (ove godine sa 898 bodova).
\end{abstract}

Ključne reči: zdravstveni sistem; evropski zdravstveni potrošački indeks; pokazatelji zdravstvenog sistema

\section{UVOD}

Zahvaljujući napretku medicine očekuje se da se živi duže, a kada nastupi bolest, da se dobijaju najdelotvorniji lekovi, odnosno da se primene neophodne dijagnostičke i medicinske tehnologije, kako u otkrivanju, tako i u lečenju raznih bolesti. Širom Evrope se s povećanjem životnog veka stanovništva povećava i incidencija hroničnih bolesti, a samim tim i finansijska opterećenost vezana za zdravstvenu zaštitu. Raste zabrinutost kako političara, tako i zdravstvenih stručnjaka, da postojeći zdravstveni sistemi neće moći da odgovore na sve veće potrebe korisnika zdravstvene zaštite. Većina zemalja pokreće reforme svojih zdravstvenih sistema u pravcu stavljanja pacijenta u fokus zdravstvene zaštite, pokušavajući da sa sve manjim javnim finansijskim sredstvima očuvaju i unaprede funkcionisanje zdravstvenog sistema.

Evropski zdravstveni potrošački indeks (engl. European Health Consumer Index - EHCI) je projekat kojim se od 2006. godine porede i rangiraju zdravstveni sistemi evropskih zemalja iz ugla pacijenata (potrošača) - korisnika zdravstvenog sistema, s osnovnim ciljem njegovog dobrog funkcionisanja i organizacije. Ovom procenom je 2014. godine bilo obuhvaćeno 36 zemalja, među kojima je bila i Republika Srbija.

Cilj ovog rada je bio da se proceni stanje srpskog zdravstva iz ugla EHCI, uporedi sa zemljama u okruženju i zemljama Evropske Unije i predlože preporuke za njegovo unapređenje i funkcionisanje u skladu s normama evropskih standarda.

\section{POKAZATELJI EFIKASNOSTI ZDRAVSTVENOG SISTEMA}

Procena zdravstvenih sistema je urađena na osnovu unapred određenih 48 pokazatelja, raspoređenih u šest grupa:

- prvu grupu su činili pokazatelji koji govore o pravima pacijenata i njihovoj informisanosti;

- druga grupa pokazatelja ocenila je dostupnost zdravstvene zaštite (čekanje na lečenje);

- treća grupa pokazatelja procenila je ishode lečenja;

- četvrta grupa je posmatrala raspon i domet pruženih usluga u zdravstvenoj zaštiti;

- peta grupa pokazatelja ocenila je prevenciju;

- šesta grupa se bavila procenom korišćenja farmaceutike.
Na osnovu pokazatelja je izvršeno bodovanje zemalja i rangiranje, pri čemu je najveća ocena za određeni pokazatelj bila 3 , a najmanja 1. Dobijeni bodovi su pomnoženi utvrđenim koeficijentom za svaku grupu pokazatelja, tako da ukupan zbir iznosi 1.000. Težinska vrednost pojedinih grupa je prikazana u tabeli 1 .

U ovom radu je izvršeno poređenje zdravstvenog sistema Republike Srbije sa zdravstvenim sistemima zemalja iz okruženja (Hrvatska, Crna Gora, Makedonija, Bugarska, Albanija i Slovenija), odnosno visokorazvijenim zemljama Evropske Unije s najviše osvojenih bodova (Italija, Španija, Holandija).

I grupa - Prava pacijenata i njihova informisanost su procenjeni na osnovu sledećih pokazatelja:

1. Zdravstveni zakon zasnovan na pravima pacijenata

2. Organizacije pacijenata

3. Osiguranje od greške u lečenju

4. Pravo na drugo mišljenje

5. Pristup svom zdravstvenom kartonu

6. Registar savesnih lekara

7. 24-časovni telefon za zdravstvenu pomoć

8. Međugranična nega finansirana od strane zemlje u kojoj je osoba državljanin

9. Katalog pružalaca usluga s ocenama

10. Dostupnost elektronskog kartona pacijentu

11. Mogućnost online zakazivanja posete lekaru

12. Elektronski recepti

Kada je reč o pravima pacijenata i njihovoj informisanosti, najveći broj bodova je ostvarila Holandija (35), a zatim Makedonija (33), koja se ovim pokazateljem izdvaja ne samo od ostalih zemalja u regionu, već i od Italije (25) i Španije (23). U ovom segmentu od Srbije (20) je bila slabija samo Bugarska (19). U tabeli 2 se uočava da je od bivših jugoslovenskih republika samo Makedonija postigla odlične rezultate u većini pokazatelja koji govore o pravima pacijenata i njihovoj informisanosti.

Srbija, iako pretposlednja sa 20 bodova, na dobrom je putu, s tim što je potrebno još da:

- unapredi uključenost pacijenata u zdravstvenu politiku kroz podizanje njihove informisanosti; 
- da oformi registar savesnih lekara i katalog rangiranih pružalaca zdravstvenih usluga; i

- da omogući dostupnost elektronskog kartona pacijentu na celoj teritoriji i obezbedi mogućnost telefonskog zakazivanja poseta lekaru, odnosno elektronsku dostupnost recepata.

\section{II grupa - Pristupačnost zdravstvenoj zaštiti (čekanje na lečenje) procenjeno je na osnovu sledećih pokazatelja:}

1. Poseta lekaru opšte medicine istog dana

2. Direktan dolazak do specijaliste

3. Čekanje na velike izabrane operacije manje od 90 dana

4. Čekanje na terapiju za kancer manje od 21 dan

5. Čekanje na CT skener manje od sedam dana

6. Čekanje na prijem u hitnu službu

Kao što se iz tabele 3 vidi, Makedonija je sa 17 bodova bila najbolja prilikom ocenjivanja dostupnosti zdravstvene službe u 2014. godini, a Španija sa 8 bodova najslabija. Srbija ima samo jedan bod više od Španije i osam bodova manje od Makedonije (17), a dostupnost zdravstvene službe je znatno slabija i od Albanije (16), Holandije (15), Slovenije (14), Hrvatske (13) i Bugarske (13). Dostupnost zdravstvene zaštite je vrlo važan pokazatelj u proceni sposobnosti zdravstvenog sistema da odgovori potrebama stanovništva.

Da bi zdravstvena služba u Srbiji postala dostupnija, potrebno je utvrditi objektivne i subjektivne razloge zbog kojih se kod nas teško dospeva ne samo do specijaliste, nego i do potrebne dijagnostike, hirurške procedure i terapije. Makedonija može da služi kao primer za unapređenje dostupnosti zdravstvene službe u Srbiji, gde je istoga dana moguća samo poseta lekaru opšte medicine (ocena 3 ).

\section{III grupa - Ishodi lečenja procenjeni su na osnovu sledećih pokazatelja:}

1. Smanjenje smrtnosti od kardiovaskularnih bolesti

2. Smanjenje smrtnosti od moždanog udara

3. Smrtnost odojčadi

4. Preživljavanje kod obolelih od kancera

5. Izgubljene godine života koje mogu da se preveniraju

6. Procenat bolničkih infekcija usled MRSA

7. Procenat abortusa

8. Procenat depresije

Ishodi lečenja, kao najvažniji pokazatelji funkcionisanja zdravstvenog sistema, jasno odvajaju ekonomski jače zemlje, kao što su Holandija (23), Španija (19), Italija (16) i Slovenija (15), od zemalja iz našeg neposrednog okruženja. Holandija, sa osvojena 23 boda u ovoj kategoriji, ima gotovo tri puta više bodova od poslednje Srbije (8). Ishodi lečenja su takođe bili nešto bolji u Hrvatskoj (15) i Crnoj Gori (15), potom u Bugarskoj (12), Albaniji (10) i Makedoniji (10) (Tabela 4).

Poražavajući izlazni efekti zdravstvenog sistema Republike Srbije, gde ni na jednom parametru nije bilo dobre ili odlične ocene, navode na potrebu ozbiljne reforme zdravstvenog sistema. Deset godina reformisanja zdravstvenog sistema, uz velika finansijska ulaganja kroz različite projekte i donacije, nije dalo nikakvog pomaka ni u jednom pokazatelju. U narednom periodu bi trebalo odgovoriti na sledeća pitanja:

- Zašto Srbija toliko kaska za ostalim evropskim zemljama, odnosno zemljama iz regiona?

- Zašto tolika projektna ulaganja u reformisanje zdravstvenog sistema nisu dala očekivane rezultate?

- Da li je ekonomska inferiornost zemlje glavni razlog loših izlaznih efekata u funkcionisanju zdravstvenog sistema?

\section{IV grupa - Raspon i domet pruženih usluga su procenjivani na osnovu sledećih pokazatelja:}

\section{Pravičnost zdravstvenog sistema}

2. Broj operacija katarakte na 100.000 stanovnika starijih od 65 godina

3. Broj transplantacija bubrega na 1.000 .000 ljudi

4. Uključenost stomatološke zaštite u javnu zdravstvenu zaštitu

5. Neformalna plaćanja doktorima

6. Dugotrajna nega za stariju populaciju

7. Dijalize urađene van klinike

8. Carski rez u odnosu na 1.000 živorođenih

U četvrtoj grupi, koja je procenjivala raspon i domet pruženih usluga u zdravstvenom sistemu, najviše bodova je dodeljeno Holandiji (24), zatim Španiji (18) i Sloveniji (18), Hrvatskoj (16), Makedoniji (15) i Italiji (14), a najmanje bodova su ostvarile Albanija i Bugarska (9). Raspon i domet pruženih usluga u Srbiji je ocenjen sa 11 bodova, što je neznatno više od Albanije i Bugarske (Tabela 5). Kroz pokazatelj broj pet (neformalna plaćanja doktorima) jasno je vidljiv problem s korupcijom u zemljama u regionu, odnosno mali broj transplantacija bubrega. Broj transplatacija bubrega je odlično ocenjen u Holandiji i Španiji, a od zemalja u okruženju samo u Hrvatskoj.

Za pohvalu u zdravstvenom sistemu Srbije je procenat dijaliza urađenih van klinika, koji je nešto bolji u poređenju sa drugim zemljama iz regiona. To pokazuje doslednost politike prebacivanja zadovoljenja potreba stanovništva na jeftinije i efikasnije metode lečenja.

\section{V grupa - Izlazni efekti prevencije procenjeni su na osnovu sledećih pokazatelja:}

\section{Vakcinacija odojčadi \\ 2. Visina krvnog pritiska \\ 3. Prevencija pušenja \\ 4. Prevencija alkohola \\ 5. Fizička aktivnost \\ 6. HPV vakcinacija \\ 7. Smrtnost u saobraćaju}

Kada je reč o izlaznim efektima preventivnih aktivnosti, najveći broj bodova je ostvarila Španija (18), a slede je Makedonija (16), Italija (16) i Slovenija (15). Najmanji broj bodova je zabeležen kod Hrvatske (10). Srbija je u zlatnoj sredini sa ostvarenih 13 bodova (Tabela 6). Pregledom pete grupe pokazatelja uočava se da je Makedonija na prevenciji postigla bolje rezultate čak i 
od prvoplasirane Holandije. Prevencija pušenja nije dala očekivane rezultate ni u jednoj zemlji u okruženju, pa ni u Holandiji, što zahteva određene korekcije, kako bi se postigla bolja efikasnost traženih parametara.

U Srbiji ima prostora za poboljšanje izlaznih efekata preventivnih aktivnosti kroz povećanje procenta vakcinisane odojčadi, većeg angažovanja na prevenciji pušenja i konzumiranja alkohola, a naročito u realizaciji Nacionalnog programa za tinejdžerke. U odnosu na zemlje iz okruženja, Srbija se ističe dobrim rezultatima sprovedenih aktivnosti na fizičkoj aktivnosti i smanjenju visine krvnog pritiska kod stanovništva.

\section{VI grupa - Korišćenje farmaceutika je procenjeno na os- novu sledećih pokazatelja:}

1. Ukupna prodaja farmaceutskih proizvoda koji su plaćeni javnim subvencijama

2. Postojanje Lajman-adaptirane farmakopeje dostupne javnosti

3. Stopa primene novih lekova za rak

4. Dostupnost novih lekova

5. Korišćenje lekova za artritis

6. Korišćenje metmorfina

7. Korišćenje antibiotika po glavi stanovnika

Procena korišćenja i dostupnosti pojedinih lekova je ponovo stavila Holandiju na prvo mesto (18), a slede je Makedonija (15), Španija (14), Slovenija (14) i Hrvatska (13). Najmanje bodova su ostvarile Crna Gora (11) i Albanija (11), a neznatno više od njih Italija (12), Bugarska (12) i Srbija (12) (Tabela 7).

Srbija je u proceni farmaceutskih pokazatelja i korišćenja proizvoda plaćenih javnim subvencijama dobila slabu ocenu. Stopa primene specifičnih novih koncepata i novih lekova za lečenje raka morala bi u Srbiji biti bolja, kao i korišćenje leko- va za terapiju artritisa, kako bi se približili zemljama Evropske Unije i zdravstveni sistem učinili efikasnijim.

\section{ZAKLJUČAK I PREPORUKE}

Zdravstveni sistem u Srbiji se, prema Evropskom zdravstvenom potrošačkom indeksu (EHCI) našao na 33. mestu sa 473 boda od maksimalnih 1.000 bodova. Na vrhu ove liste je već godinama Holandija, koja je ove godine ostvarila 898 bodova. Ovo rangiranje i primenjeni parametri omogućavaju jasan uvid u to šta je u zdravstvu Republike Srbije dobro, a šta treba da se poboljša, kako bi se došlo do glavnog cilja, a to je zadovoljan i zdrav korisnik (potrošač) zdravstvenog sistema.

Pozitivni pomaci u Srbiji su učinjeni u poboljšanom pristupu lekarima primarne zdravstvene zaštite, poboljšanoj dostupnosti podacima o lekovima, povećanom procentu dijaliza urađenih van klinike, kao i dobri rezultati sprovedenih aktivnosti na smanjenju visine krvnog pritiska kod stanovništva.

Da bi korisnik zdravstvene zaštite u Republici Srbiji bio zdraviji i zadovoljniji, trebalo bi poboljšati:

- uključenost pacijenata u zdravstvenu politiku i obaveštenost pacijenata,

- aktivnosti na prevenciji i promociji,

- aktivnosti na smanjenju nepovoljnih ishoda lečenja,

- aktivnosti na smanjenju nejednakog pristupa zdravstvenoj zaštiti,

- aktivnosti na smanjenju smrtnosti odojčadi,

- aktivnosti na smanjenju procenta obolelih od kancera,

- aktivnosti na sprečavanju korupcije u zdravstvu.

Procena efikasnosti zdravstvenog sistema u Srbiji iz ugla EHCI omogućava i definisanje preporuka za unapređenje srpskog zdravstva, kako bi ono funkcionisalo u skladu s normama evropskih standarda, i zadovoljstva samih korisnika. 